\title{
STUDY OF AGROCHEMICAL AND PHYSICAL-CHEMICAL PROPERTIES GRAY-BROWN SOILS OF THE KARABAKH PLAIN
}

\author{
COsmanova S., Ph.D., Institute of Soil Science and Agrochemistry ANAS, \\ Baku, Azerbaijan, osmanova-sona@mail.ru
}

\section{ИЗУЧЕНИЕ АГРОХИМИЧЕСКИХ И ФИЗИКО-ХИМИЧЕСКИХ СВОЙСТВ СЕРО-КОРИЧНЕВЫХ ПОЧВ КАРАБАХСКОЙ РАВНИНЫ}

\author{
СОсманова С. А., канд. с.-х. наук, Институт почвоведения и агрохимии НАН \\ Азербайджана, г. Баку, Азербайджан, оsтапоvа-sona@mail.ru
}

\begin{abstract}
Research is conducted at the Terter Regional Experimental Station of the Research Institute for Agriculture. In order to improve the fertility of gray-brown soils and obtain highquality crop yields, we studied the agrochemical and physical-chemical properties of the experimental plot. Thus, the analysis of gray-brown soils showed that, according to the gradation adopted in Azerbaijan, these soils are poorly supplied with nutrients, in an easily digestible form of plants. Therefore, it is necessary to make in these soils together organic and mineral fertilizers.
\end{abstract}

Аннотащия. Исследования проводились на Тертерской региональной опытной станции Научно-исследовательского института земледелия. С целью улучшения плодородия серокоричневых почв и получения высоких и качественных урожаев сельскохозяйственных культур мы изучили агрохимические и физико-химические свойства опытного участка. Таким образом, проведенный анализ серо-коричневых почв показал, что согласно градации принятой в Азербайджане, эти почвы слабообеспечены элементами питания, в легко усвояемой растениями форме. Поэтому, необходимо вносить в эти почвы совместно органические и минеральные удобрения.

Keywords: gray-brown soil, fertility, agrochemical properties, physical-chemical properties.

Ключевые слова: серо-коричневые почвы, плодородие, агрохимические свойства, физико-химические свойства.

\section{Introduction}

Scientific studies show that in the world from the soils used under crops of crops, annually with a crop of nutrients is 5 times more than is applied with fertilizers. Therefore, at present in agriculture, there is a negative balance. Most of the crop produced in intensive agriculture is formed by natural fertility. At present, $46 \%$ of soils are poorly supplied with humus, $22 \%$ with mobile phosphorus and about $10 \%$ with exchangeable potassium, and $31 \%$ of soils have increased acidity, etc. To preserve and restore soil fertility, improve the ecological situation and obtain high productivity from agroecosystems, optimization of agrochemical agents is required [1]. 
In many studies conducted in the Russian Federation, there has been a decrease in natural fertility and a slow rate of its recovery. To restore the indicators of soil fertility and the structure of the soil cover in the soil, it is necessary to apply a sufficient amount of organic fertilizers. Studies show that in the modern period the restoration of their fertility remains the main problem, both in heating and in soil irrigation conditions. In the Rostov region of Russia for a long time the application of small doses of mineral fertilizers and the complete absence of organic fertilizers led to a negative balance of nutrients in the soil, and as a result - a decrease in its natural fertility. Therefore, it is very important to use local resources as fertilizers and ameliorants [2].

\section{Research methodology}

Research is conducted at the Terter Regional Experimental Station of the Research Institute for Agriculture. To study the agrochemical and physicochemical properties of the soils of the experimental plot, before the laying of the experiment, soil samples were taken, and analyses were carried out in the laboratory. In the selected soil samples were determined: $\mathrm{pH}$ - potentiometer, total humus - according to Turin, granulometric composition - according to N. A. Kachinsky, absorbed bases - according to K. K. Gedroits, absorbed ammonia - according to D. P. Konev, nitrate nitrogen - Grandval-Lyazhu, total nitrogen, total phosphorus - according to K. E. Ginzburg and G. M. Shcheglov, mobile phosphorus - according to B. P. Machigin, total potassium - according to Smith, exchange potassium - P. B. Protasova on a flame photometer, volumetric weight and total porosity in the modification of N. A. Kachinsky and according to a simplified calculation by V. Zaitsev, soil moisture $\mathrm{s}$ - at $105^{\circ} \mathrm{C}$ with drying in thermostat [4].

\section{Results and discussion}

To solve the problems of fertility and reduce costs, optimization of complex agrotechnical measures in agriculture is required. In recent years, due to soil degradation, the alarm is sounding, which is justified, since in the future it will be very difficult to restore these soils. The content of humus decreases annually in all soil types. It is known that perennial grasses, accumulating a large amount of root mass in the soil, contribute to the accumulation of humus and increase soil fertility.

The number of nutrients in the soil and constitute the main agrochemical indicators of soil fertility. Depending on the type of soil and the degree of its fertility, in the $0-40 \mathrm{~cm}$ soil layer usually contains $6-30$ tons of nitrogen, 3-15 tons of phosphorus and 12-45 tons of potassium. The degree of supply of plants with nutrients depends on their stock in the soil and the form of their existence.

The nutritional needs of plants in agriculture are ensured by the transformation of the organic substances of the soil into assimilable forms and the introduction of mineral fertilizers.

Improvement of agrochemical indicators of soil fertility is achieved by the following way: liming acidic and gypsum alkaline soils, washing saline soils, introducing organic and mineral fertilizers, proper placement of plants and alternating crops.

The soil, which appeared as a result of prolonged exposure to the rock of physical, chemical and biological processes, and which has become a biokos body, consists of solid, liquid and gaseous phases. The solid phase consists of multifunctional minerals and organic substances, which in turn affect the change in the liquid and gaseous phases. According to various properties of soil phases, it has a number of agrophysical properties. These properties, appearing as a result of the processes of soil formation and its use, are considered to be the main indicators of fertility and, above all, affect its biological productivity [3]. 
In order to achieve a predictable, stable crop, it is necessary to organize the correct diet for crops. And this is possible only when the amount of nutrient reserves is clarified, and the effective rates of fertilizers are determined according to the biological characteristics of the crops grown.

The research results showed that it is impossible to determine the need for fertilizers by the amount of the total content of nutrients in the soil. But this does not mean that one should not study the total nutrient content in the soil. Without this, it is impossible to determine the potential fertility of the soil. For example, in the basic soil types of Azerbaijan, the total content of phosphorus compounds in comparison with the demand of crops is disproportionately large, but without phosphate fertilizers, it is not possible to obtain high and high-quality yields of crops. From this it follows that the gross (total) quantities of nutrients in the soil cannot show the degree of its availability of this element, only under the condition of high agrotechnical measures, it is gradually absorbed by the plant. As the same type of soil may belong to different zones, its diet may also be different. For example, while in the grey soils of the Ujar region there is $158 \mathrm{mg}$ of $\mathrm{P}_{2} \mathrm{O}_{5}$ in the topsoil (per $100 \mathrm{~g}$ of soil), then only $79 \mathrm{mg} / 100 \mathrm{~g}$ of soil is contained in the same type of soil of the Kurdamir region. This means that the same type of soil in different zones is provided with different nutrients. Without taking into account the availability of nutrients to the soil, fertilization will not only increase the crop yield but, on the contrary, may reduce it. Thus, according to the gradations adopted in the republic, if the site is provided with mobile forms of phosphorus, the introduction of phosphate fertilizers will not only have any effect but, on the contrary, will have a negative impact on the harvest. This is explained by the fact that a high concentration of any element in the soil solution makes it difficult for plants to assimilate this element, which delays the growth and development of the plant. In this case, only during the sowing of seeds, a low dose of fertilizer can be given to ensure the normal germination of the plants. After the plant takes root, i. e. will strengthen its root system, the need for such feeding will disappear. Therefore, specialists in farms should use cartograms of the nutritional status of the soil of the farm and amend them periodically [4].

The land is a means of agricultural production and the basis of an agroecosystem. Humanity gets $95 \%$ of its food from the soil. The preservation of soil fertility (health) is a priority for all agricultural production. The soil is a living environment for living organisms. The soil has a supporting function for vegetation on Earth.

The soil protects and preserves the seeds of plants and thus fulfils an irreplaceable function and plays an important role in the conservation of vegetation on Earth. This ensures the ability to update plant populations and preserve biodiversity in nature.

The soil accumulates in itself the primary producers, (water, food, energy) necessary for the life of living organisms living in it and on it, which ensures its fertility.

The soil is a kind of depot, a warehouse of peculiar enzymes. The soil regulates the hydrothermal regime, which provides a certain temperature and water regime to maintain the vital activity of the organisms living in it.

Soil fatigue is observed, first of all, in a sharp decrease in the yield of agricultural crops, which usually occurs with prolonged cultivation of the same crop (monoculture). Often, soil exhaustion occurs when re-sowing of flax, sunflower, cotton, sugar beet and other crops. It is believed that soil fatigue occurs due to the excretion of monocultures by roots and microorganisms, specific pests of specific toxic substances.

Soil pollution can be easily prevented. To do this, observe alternation of crops and crop rotation, make organic fertilizers, plant green manure, use resistant plant varieties, etc. [5].

In the gray-brown soils, common in the northwestern foothill-flat semi-zone of the Lesser Caucasus, in the $0-27 \mathrm{~cm}$ layer the amount of hygroscopic moisture was $5.61 \%$, in the $83-105 \mathrm{~cm}$ 
layer $-5.82 \%$, the content of humus, total nitrogen and phosphorus, respectively, $2.5-0.49 \%$, $0.181-0.055 \%, 0.175-0.112 \%$. In a layer of $0-27 \mathrm{~cm}$, the sum of absorbed bases is $29.82 \mathrm{mg} / \mathrm{eq}$ and $\mathrm{Ca}^{2+}-17.11 \mathrm{mg} / \mathrm{eq}, \mathrm{Mg}^{2+}-10.19 \mathrm{mg} / \mathrm{eq}$, and in a layer of $27-48 \mathrm{~cm}$, respectively, were: 18.5 $\mathrm{mg} / \mathrm{eq}, 12.65 ; 3.87$ and $1.98 \mathrm{mg} / \mathrm{eq}$.

Studies have shown that depending on the agroecological state of the area in the fertility indicators of these soils there have been some changes. So, for example, in comparison with studies conducted 30-40 years ago, both in the arable layer and throughout the profile of these soils, a decrease in humus is observed. In the content of gross quantities of nitrogen and phosphorus over the past 40 years, no significant changes have occurred. As for the number of absorbed bases, they increased and decreased for years over this period [6].

When studying the basic physicochemical parameters of grey-brown soils, it was found that in the $0-30 \mathrm{~cm}$ layer of long-irrigated grey-brown soils the humus content was $2.68 \%$, total nitrogen $-0.174 \%, \mathrm{pH}$ of the aqueous extract -7.2 , the absorbed bases in 100 grams of soil amounted to only $30.47 \mathrm{mg} / \mathrm{eq}$, in ordinary grey-brown soils, respectively $-2.88 \% ; 0.203 \% ; 7.1$ and $29.72 \mathrm{mg} /$ eq. In light gray-brown soils, respectively, accounted for $2.21 \% ; 0.171 \%$; 74 and $30.93 \mathrm{mg} /$ eq. [7].

According to S. Z. Mamedova, one of the main conditions for the intensification of agriculture is the study of the agrochemical and water-physical properties of the soil cover and the determination of the methods, timing and application rates of mineral fertilizers [8].

According to academician M. P. Babayev, in the modern period, one of the most important tasks facing agricultural specialists is to increase soil fertility and crop yields. It is known that the use of soil under crops reduces its fertility. Under the influence of natural and anthropogenic factors, they are subject to degradation. In degraded soils, the water-physical properties worsen, the particle size distribution becomes heavier, the humus content decreases. The decomposition of humus results in the separation of nitrogen and, as a result, it is absorbed by the plant, which leads to an increase in the productivity of plants [9].

In studies of soils conducted on the northwestern slopes of the Lesser Caucasus, it was shown that the particle size and chemical composition of these brown mountain forest soils is clay and loamy.

For example, the content of physical clay in them was 52.00-67.69\%. In the mountain soils of brown mountainous silt, fractions vary in the range of 18.40-28.54\%. Hygroscopic humidity along the profile varies within 4.94-6.71\%. According to the results of chemical analysis, it can be seen that in mountain brown soils the humus content varies between $0.52-4.32 \%$, total nitrogen is $0.067-$ $0.305 \%$. $\mathrm{pH}$ along the profile is 6.0-6.2. The content of the number of absorbed bases was 15.90 $44.15 \mathrm{mg} / \mathrm{eq}$. for every 100 grams of soil. Of these, $2.0-2.51 \%$ is accounted for by the hydrogen cation [10].

In studies conducted in the conditions of the Samukh region in the upper layer $(0-18 \mathrm{~cm})$ of light grey-brown soils, the humus content was $2.20 \%$; in the lower layers $(46-89 \mathrm{~cm})-0.30 \%$. Accordingly, the content of hydrolysable nitrogen is 54.6 and $32.6 \mathrm{mg} / \mathrm{kg}$, mobile phosphorus $17.6-16.8 \mathrm{mg} / \mathrm{kg}$; exchange potassium - 188.2-186.4 mg/kg.

N. Agayev, in his studies conducted in the zone of the Lesser Caucasus, distinguishes that by their particle size distribution these soils are clayey and heavy loamy. Basically — carbonate by the reaction of the soil environment - neutral and alkaline ( $\mathrm{pH}$ 7.0-9.2) [1]. In these soils, there is relatively much humus. In the upper layers, the average amount of humus is $2.43 \%$. In these layers, the content of total nitrogen, phosphorus and potassium, respectively, was $0.13 ; 0.15$ and $2.85 \%$. And the content of easily hydrolyzed nitrogen, mobile phosphorus and exchangeable potassium, respectively, was $73.0 ; 15.5$ and $315.4 \mathrm{mg} / \mathrm{kg}$. 
Light grey-brown soils are less rich in nutrients than ordinary grey-brown soils. And by the amount of humus, these soils are considered poorly secured. If in the $0-20 \mathrm{~cm}$ layer the humus content was $2.08 \%$, then in the $80-100 \mathrm{~cm}$ layer its amount was only $0.26 \%$. The content of nitrogen, phosphorus and potassium in digestible forms in the upper layers is higher than in the lower ones, which can be explained by the high content of humus in the upper layers compared to the lower.

When studying the fertility indicators of light gray-brown soils, the total amount of humus, nitrogen, phosphorus and potassium in the $0-20 \mathrm{~cm}$ layer was found to be: $2.03 ; 0.15 ; 0.13 ; 2.45 \%$, and in the layer of $80-100 \mathrm{~cm}$, respectively, $0.35 ; 0.03 ; 0.06 ; 1.51 \%$. Mobilized phosphorus was 6.3-2.3; exchange potassium - 232.0-104.2; ammonia absorbed 20.3-1.8; nitrate nitrogen - 12.0$1.6 \mathrm{mg} / \mathrm{kg}[11]$.

Analysis of soil samples showed that grey-brown soils are not provided in a high dose of digestible forms of nitrogen, phosphorus and potassium. The $\mathrm{pH}$ of the aqueous extract from $0-30$ $\mathrm{cm}$ layer is equal to 7.4, and down along the profile it increases slightly and reaches up to 7.9 in a 60-100 cm layer. The content of gross quantities of humus, nitrogen, phosphorus and potassium in the $0-30 \mathrm{~cm}$ layer was $2.11 ; 0.13 ; 0.12$ and $2.39 \%$. However, down the profile, these values greatly decreased and the $60-100 \mathrm{~cm}$ layer, respectively, was: $0.73 ; 0.05 ; 0.07$ and $1.55 \%$. The amount of absorbed ammonia varied within 18.3-6.5; nitrate nitrogen - 9.7-2.3; mobile phosphorus 16.3-4.9; exchangeable potassium is $273.5-95.3$ [12].

To determine the content of nutrients in the soils of the experimental area before laying the experiment, their potential reserves in the form of gross quantities of humus, nitrogen, phosphorus, potassium and effective fertility, that is, the number of their easily digestible forms were identified.

Analysis of soil samples showed that they are not sufficiently well provided with assimilable forms of nitrogen, phosphorus and potassium. The results of the analyzes are presented in Table 1. As can be seen from the table, the $\mathrm{pH}$ of the aqueous extract in the $0-30 \mathrm{~cm}$ layer was 7.8 , and down the soil profile in the $60-100 \mathrm{~cm}$ layer, this indicator was equal to the value of 8.4 . The total content of humus, nitrogen, phosphorus and potassium in the $0-30 \mathrm{~cm}$ layer was: $2.15 ; 0.15 ; 0.13$ and $2.39 \%$.

Table 1.

AGROCHEMICAL SOIL FEATURES OF THE EXPERIMENTAL PLOT

\begin{tabular}{|c|c|c|c|c|c|c|c|c|c|}
\hline \multirow[b]{2}{*}{ 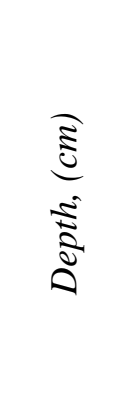 } & \multirow[b]{2}{*}{ 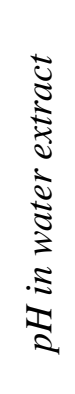 } & \multirow[b]{2}{*}{ 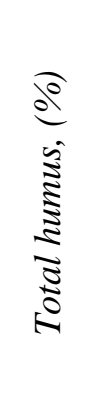 } & \multicolumn{3}{|c|}{ Nitrogen } & \multicolumn{2}{|c|}{ Phosphor } & \multicolumn{2}{|c|}{ Potassium } \\
\hline & & & 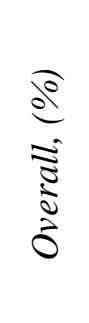 & 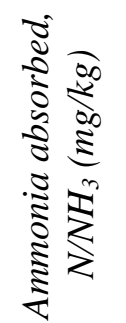 & 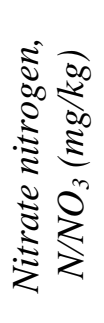 & 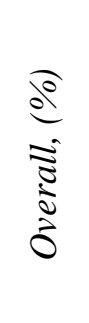 & 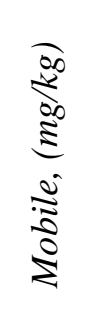 & 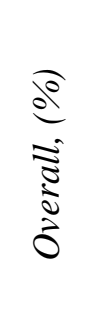 & 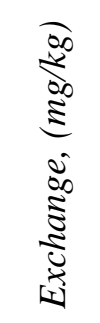 \\
\hline $0-30$ & 7.8 & 2.15 & 0.15 & 18.0 & 9.7 & 0.13 & 15.8 & 2.39 & 263.5 \\
\hline $30-60$ & 8.2 & 1.17 & 0.09 & 12.6 & 5.4 & 0.09 & 8.0 & 1.85 & 165.0 \\
\hline 60-100 & 8.4 & 0.85 & 0.06 & 6.5 & 2.6 & 0.07 & 4.5 & 1.51 & 105.3 \\
\hline
\end{tabular}

However, down the soil profile, these indicators in the $60-100 \mathrm{~cm}$ layer have already amounted to $0.85 ; 0.06 ; 0.07$ and $1.51 \%$. The amount of absorbed ammonia nitrogen was $18.0-6.5$; nitrate nitrogen - 9.7-2.6; mobile phosphorus $15.8-4.5$; exchangeable potassium is $263,0-105.3$ 
$\mathrm{mg} / \mathrm{kg}$. These soils according to the graduation, adopted in our republic, are considered low humus by the content of humus.

At the same time, along with agrochemical indicators, the main physic-chemical indicators of the soil of the experimental plot were studied (Table 2). As can be seen from Table 2, the number of absorbed bases in the 0-30 cm layer is equal to $29.8 \mathrm{mg} / \mathrm{eq}$, and in the $60-100 \mathrm{~cm}$ layer decreasing, amounted to $21.1 \mathrm{mg} / \mathrm{eq}$. The amount of physical clay was $53.5 \%$ and $54.5 \%$, respectively, the amount of sludge -24.2 and $22.3 \%$, density $-1.19-1.31 \mathrm{~g} / \mathrm{cm}^{3}$. According to the gradation of R. Mamedov, these soils are considered to be light clay in terms of particle size distribution [13].

Table 2 .

THE MAIN PHYSIC-CHEMICAL CHARACTERISTICS OF THE SOIL OF THE EXPERIMENTAL SITE

\begin{tabular}{cccccccc}
\hline \multirow{2}{*}{ Depth, $\mathrm{cm}$} & \multicolumn{3}{c}{$\begin{array}{c}\text { Absorbed bases in 100 } \mathrm{g} \text { of } \\
\text { soil, } \mathrm{mg} / \mathrm{eq}\end{array}$} & $\begin{array}{c}\text { The number of } \\
\text { absorbed bases, }\end{array}$ & \multicolumn{2}{c}{ Grading, \% } & \multirow{2}{*}{$\begin{array}{c}\text { Density, } \\
\end{array}$} \\
\cline { 2 - 3 } & $\mathrm{Ca}$ & $\mathrm{Mg}$ & $\mathrm{Na}$ & $\mathrm{mg} / \mathrm{eq}$ & $<0.001 \mathrm{~mm}$ & $<0.01 \mathrm{~mm}$ & \\
\hline $0-30$ & 20.5 & 7.5 & 1.5 & 29.8 & 24.2 & 53.5 & 1.19 \\
$30-60$ & 18.4 & 6,8 & 0.8 & 26.0 & 25.0 & 56.2 & 1.28 \\
$60-100$ & 16.3 & 4,3 & 0.5 & 21.1 & 22.3 & 54.5 & 1.31 \\
\hline
\end{tabular}

\section{Conclusion}

Thus, the analysis of grey-brown soils showed that according to the gradation adopted in our republic, these soils are poorly supplied with nutrients, digestible by plants form. Therefore, in order to preserve the fertility of these soils and to obtain high and high-quality yields of agricultural crops, it is necessary to bring together organic and mineral fertilizers into these soils.

\section{References:}

1. Agaev, N. A., Ismailova, S. N., \& Agaev, N. N. (1999). Agrochemical features of some soils of Azerbaijan. Agrarian Science of Azerbaijan, (3-4), 20-33.

2. Tkacheva, O. A., \& Menaninova, E. G. (2013). Ecological and economic aspects of the sustainability of agricultural farming use. Scientific journal of the Russian Research Institute of Land Reclamation Problems, (1), 13. (in Russian).

3. Gadzhiev, D. A., \& Guseynov, M. M. (2009). Agriculture. Baku, Araks, 354.

4. Jafarov, M. I. (2005). Soil science. Baku, Elm, 460.

5. Mamedov, G. Sh., Khalilov, M. Yu., \& Mamedova, S. Z. (2010). Agroecology. Baku, Elm, 552.

6. Gasimov, N. M. (2007). Agroecological features of some soil types, common in the northern foothill subzone of the Lesser Caucasus. Agrarian Science of Azerbaijan, (6-7), 123-125.

7. Bashirov, V. V. (2010). Forms of the food supply in the soil, factors affecting their use of wheat and barley plants. In: materials of the scientific-practical conference of young scientists, ASAU. Ganja, Ed. AGAU, 23.

8. Mamedova, S. Z., \& Jafarov, A. B. (2006). Soil fertility property. Baku, Elm, 194.

9. Babaev, M. P. (2003). Soil degradation. Baku, Elm, 44.

10. Sadigov, R. A. (2013). The influence of erosion processes on the parameters of soil fertility in the zone of mountain farming on the northeastern slope of the Lesser Caucasus: Ph.D. diss. Baku, 19.

11. Gasimova, F. N. (2011). Fertilizer of potato plants on the basis of the balance of batteries: Ph.D. diss. Baku, 19. 
12. Hasanov, A. O. (2012). Agrochemical features of the soil of the experimental site. Agrarian Science of Azerbaijan, (1), 168-169.

13. Mamedov, R. G. (1989). Agrophysical properties of the soils of the Azerbaijan SSR. Baku, Elm, 244.

\section{Список литературы:}

1. Агаев Н. А., Исмаилова С. Н., Агаев Н. Н. Агрохимические особенности некоторых почв Азербайджана // Аграрная наука Азербайджана. 1999. №3-4. С. 20-33.

2. Ткачева О. А., Мензанинова Е. Г. Эколого-экономические аспекты устойчивости сельскохозяйственного земледелие пользования // Научный журнал Российского НИИ проблем мелиорации. 2013. №1 (109). С. 13.

3. Гаджиев Д. А., Гусейнов М. М. Земледелие. Баку: Аракс, 2009. 354 с.

4. Джафаров М. И. Почвоведение. Баку: Элм, 2005. 460 с.

5. Мамедов Г. Ш., Халилов М. Ю., Мамедова С. З. Агроэкология. Баку: Элм,2010. 552 с.

6. Гасымов Н. М. Агроэкологические особенности некоторых типов почв, распространенных в северной предгорной подзоне Малого Кавказа // Аграрная наука Азербайджана. 2007. №6-7. С. 123-125.

7. Баширов B. В. Формы запаса питания в почве, факторы, влияющие на их использование растениями пшеницы и ячменя // Материалы научно-практической конференции молодых ученых. Гянджа: Изд-во АГАУ, 2010. С. 23.

8. Мамедова С. З., Джафаров А. Б. Свойство плодородия почв. Баку: Элм, 2006. 194 с.

9. Бабаев М. П. Почвенная деградация. Баку: Элм, 2003. 44 с.

10. Садыгов Р. А. Влияние процессов эрозии на параметры плодородия почв в зоне горного земледелия на северо-восточном склоне Малого Кавказа: автореф. дисс. ... канд. наук. Баку, 2013. 19 с.

11. Гасымова Ф. Н. Удобрение растений картофеля на основе баланса элементов питания: автореф. дисс. ... канд. наук. Баку, 2011. 19 с.

12. Гасанова А. О. Агрохимические особенности почв опытного участка // Аграрная наука Азербайджана. 2012. №1. С. 168-169.

13. Мамедов Р. Г. Агрофизические свойства почв Азербайджанской ССР. Баку: Элм, 1989. $244 \mathrm{c}$.

Работа поступила

Принята к публикациии

в редакичию 17.01.2019 2. 21.01.2019 2.

Cite as (APA):

Osmanova, S. (2019). Study of agrochemical and physical-chemical properties gray-brown soils of the Karabakh Plain. Bulletin of Science and Practice, 5(2), 135-141. https://doi.org/10.33619/2414-2948/39/18.

Ссылка для цүитирования:

Osmanova S. Study of agrochemical and physical-chemical properties gray-brown soils of the Karabakh Plain // Бюллетень науки и практики. 2019. Т. 5. №2. С. 135-141. https://doi.org/10.33619/2414-2948/39/18. 